\title{
The effects of fires on plant and wildlife species diversity, and soil physical and chemical properties at Aberdare Ranges, Kenya
}

\author{
WANGARI FAITH NJERI ${ }^{1}$, J. M. GITHAIGA ${ }^{1, \boldsymbol{\nu}}$, AGGREY K. MWALA ${ }^{2}$ \\ ${ }^{1}$ School of Biological Sciences, University of Nairobi, Nairobi, Kenya. ^email: jmgithaiga@uonbi.ac.ke, mainagithaiga@gmail.com \\ ${ }^{2}$ Department of Land Resource Management and Agricultural Technology, University of Nairobi. Nairobi, Kenya
}

Manuscript received: 12 March 2018. Revision accepted: 6 June 2017.

\begin{abstract}
Njeri WF, Githaiga JM, Mwala AK. 2018. The effects of fires on plant and wildlife species diversity and soil physical and chemical properties at Aberdare Ranges, Kenya. Asian J For 2: 25-38. Forest fires have devastating impacts on the biodiversity and biophysical elements of forest ecosystems. Yet, little is known of the impacts of forest fires in a lesser-known region such as Kenya. This study was aimed to determine the effects of fires on species diversity (plants, animals, birds), and soil physical and chemical properties at the Aberdare Ranges forest, Kenya. Data were collected on five sites that experienced fires in 2002, 2009, 2012, 2013, and 2014 from both burnt and unburnt areas. Point Centered Quarter and quadrant methods were used for woody vegetation sampling and herbaceous vegetation sampling, respectively. Foot count was done for animal census and point count for birds. The data showed that the herbaceous vegetation in burnt sites had significantly higher species diversity than the unburnt sites in the are as that experienced fire before 2014. The fire had triggered the regeneration of the herbaceous plants. The burnt sites had a significantly higher percentage cover. The fire had an immediate adverse effect on the population of animals as demonstrated on the site consumed in 2014. No animal species were found on the site seven days after the fire when data was collected. The animal diversity was proportional to the vegetation density caused by the vegetation regeneration due to fires. All the burnt sites had fewer birds than the unburnt sites. Effects of fires were prominent in the upper layer of the soil for all the soil properties under study. Burning caused an increase in $\mathrm{pH}$, potassium, organic carbon and cation exchange capacity. The study demonstrated that fires lead to an immediate adverse effect on vegetation, wildlife and soil chemical properties. Postfire management is necessary on sites that have recently experienced fires to rehabilitate them. Authorities responsible for the management of forests must ensure that people are kept out of those sites to allow vegetation to recover without interference. Reforestation can also be done on the burnt sites to increase plants and habitat for the wildlife.
\end{abstract}

Keywords: Animal diversity, birds, fire, plant diversity, soil properties

\section{INTRODUCTION}

Forests are indispensable sources of products and they deliver a variety of ecosystem services including provision of food, timber, fuel, genetic materials among others, regulating services (e.g., protection of watershed and carbon storage), cultural values and supporting services (Koziowski 2002). Forest ecosystem services have been shown to be of high economic value since they provide raw materials for food, fuel, and shelter (Constanza et al. 1997). In forest valuation studies, non-tangible service components such as carbon storage or hydrological protection frequently fetch higher values than forest products.

Old-growth forests are a valuable component of biodiversity, and one way to assess the effectiveness of forest management is by evaluating the proportion of oldgrowth forests currently present concerning that was historically present (Lesica 1996). However, forests throughout the world, and especially old-growth forests in the tropics, are threatened by natural-induced disturbances such as windthrow, droughts, floods, disease and outbreaks, and human-induced disturbances such as fires, logging, charcoal burning and forest clearance for farming (Koziowski 2002).

One phenomenon that threatens forests worldwide is forest fires. Forest fire can be defined as the widespread uncontrolled fire in forest ecosystems, caused by accidental, natural or intentional causes (Chuvieco 2009). Forest fires are a severe hazard and can cause considerable damage to ecological, economic, cultural, and human resources (Long et al. 2001).

Knowledge on the impacts of forest fire has attained increased importance to land managers because fire as a disturbance process is a part of ecosystem management. Fire can initiate changes that affect the composition, structure, and pattern of vegetation on the landscape. A disturbance is necessary to maintain a diversity of living things and processes (Botkin 1990; Morgan et al. 1994). Anthropogenic activities create fire-prone ecosystems in the tropics through the alteration of vegetation cover by logging, burning, and development. The new ecosystems differ substantially in carbon budget, nutrient cycling, fuel and habitat characteristics (Swetnam et al. 1999).

More than 220,000 events of fires occur in a year around the world with burning extent of more than 6 million ha of forests (Gonzalez et al. 2005). Many studies have been conducted on the assessment and management of forest fires. Some countries like Russia, the United States of America and Canada have led the way in forest fire research (Sturtevant et al. 2009) by developing forest fire management systems and forest fire risk forecast systems temporally and spatially. Kenya is also adopting a fire 
management system through Kenya Forest Service by recording all the fire incidences and stocking every station with fire equipment although the progress has been slow.

As one of Kenya's five main water towers, the forests of the Aberdares play a critical role in supporting the country's economy. They are the primary source of water for Nairobi. Furthermore, 55\% of Kenya's electricity is generated by water flowing from Aberdares and Mt. Kenya. The Aberdares are the main catchments for Sasumua and Ndakaini dams, which mainly act as the water source for Nairobi, a city of more than three million people that accounts for $60 \%$ of Kenya GDP. The energy, water and some raw materials used to drive some economic activities in the city and its environment are derived from the Aberdare ecosystem. Proper management of this ecosystem is crucial for the national economy (Ark 2011). Nevertheless, fires may interfere with the ability of Aberdares to continue providing its services hence affecting the national economy.

This study was carried out in the western Aberdares at Geta forest zone. The specific objectives were (i) to determine the effect of fire on plant species diversity at different time periods; (ii) to assess the impact of fire on a population of herbivores and birds at different time periods; (iii) and to determine the effects of fire on soil physical and chemical properties at a different period.

In doing so, five sites that had been burnt at different periods were identified, and data were collected in both burnt sites and unburnt sites. The data were collected during the wet season and dry season. Point Centered Quarter method was used for the woody vegetation, whereas the quadrant method was employed for the herbaceous plant. Herbivores were counted using foot count, and the birds were counted using point count. Soil samples were collected from all the sites and taken to a soil laboratory for physical and chemical analysis. The soil properties analyzed include $\mathrm{pH}$, nitrogen, organic matter, potassium, phosphorous, and Cation Exchange Capacity.

\section{MATERIALS AND METHODS}

\section{Study area}

Geographic location

The study was carried out in the Aberdare Range, part of Kenya which is close to the equator (Figures 1 and 2). It is the third highest mountain in Kenya, with two central peaks: Oldonyo Lesatima (also known as Sattima) and Kinangop, which are at altitudes of 4,001 and 3,906 meters above sea level respectively. The Range presents a deeply dissected topography sloping gradually to the east. In contrast, the western side drops along impressive fault escarpments towards the Rift Valley (www.britannica.com retrieved 2014-06-17). The Aberdare mountain range lies between Latitude $00^{\circ} 00^{\prime \prime}-01^{\circ} 00^{\prime \prime}$ South and Longitude $36^{\circ}$ $30^{\prime \prime}-36^{\circ} 55^{\prime \prime}$ East running in an NNW-SSE direction. Altitude varies from $1850 \mathrm{~min}$ at the lower parts to about $4000 \mathrm{~m}$ at the highest point.

In the context of this study, data collection was done at Geta forest zone which is at the western side of the
Aberdares and the most significant part of the Aberdares hills. Data was also collected from Kipipiri hill which lies next to the Aberdare ranges.

\section{Climate of Aberdare Ranges}

Altitude largely determines the environment of the Aberdare Ranges. The rainfall distribution is greatly influenced by the movement of inter-tropical convergence zones of air masses of the southern and northern hemispheres. It is characterized by two rainy seasons: long rains from April to May, and short rains from October to November. Rainfall reaches a maximum of around 2,600 $\mathrm{mm}$ annually on the south-eastern slopes but varies with altitude and exposure to the dominant wind from the Indian Ocean (Butynski 1999). On the western part, rainfall reduces sharply from about $1,400 \mathrm{~mm}$ at the forest border to less than $700 \mathrm{~mm}$ in the valley of the Malewa River.

The northern end of the range has 3-4 dry months per year with the seasonal distribution showing three rainfall peaks: March-May (long rains), July-August, and November. Elsewhere, the rainfall distribution is bimodal with peaks in April-May and October-November and only 1-2 dry months each year. Temperature decreases with increase in altitude and rainfall also decline with elevation.

\section{Vegetation in Aberdare Ranges}

Vegetation zones in the Aberdare Ranges include the bamboo zone, the closed-canopy forest belt, and the subalpine and alpine vegetation. The forest belt covers a significant part of the range. Most of the forest is gazetted as forest reserves. The key trees and shrubs species at the Aberdares are shown in Table 1.

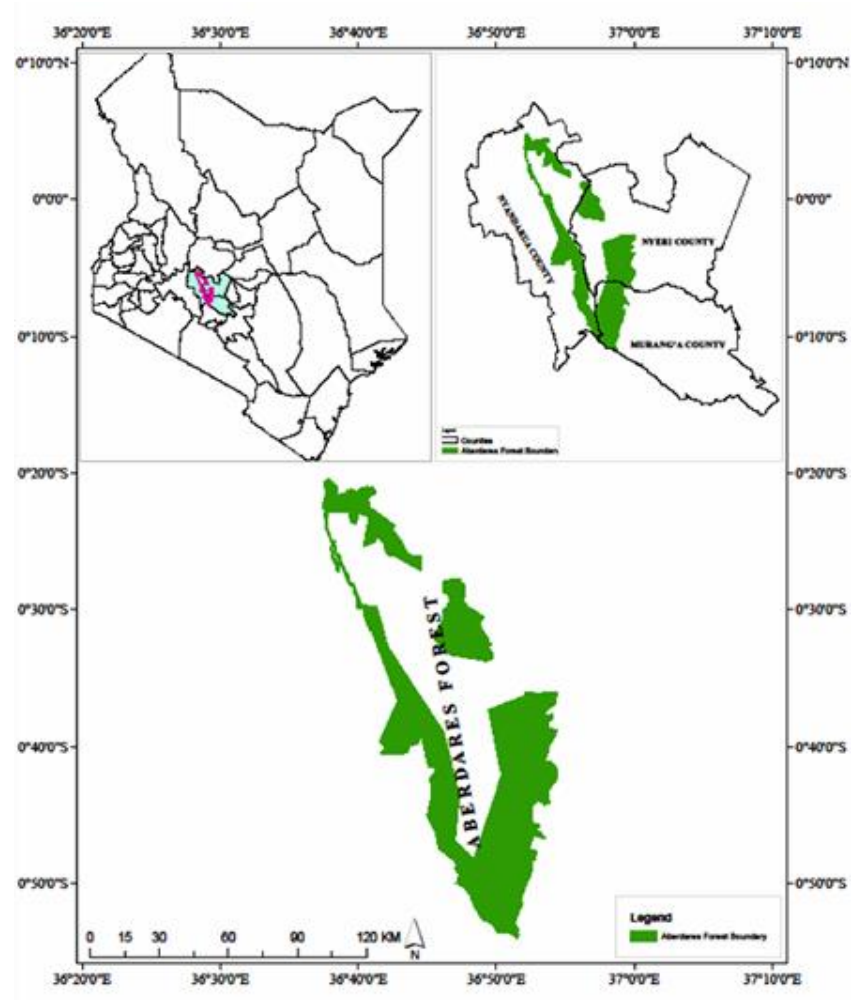

Figure 1. The location of Aberdares in Kenya 


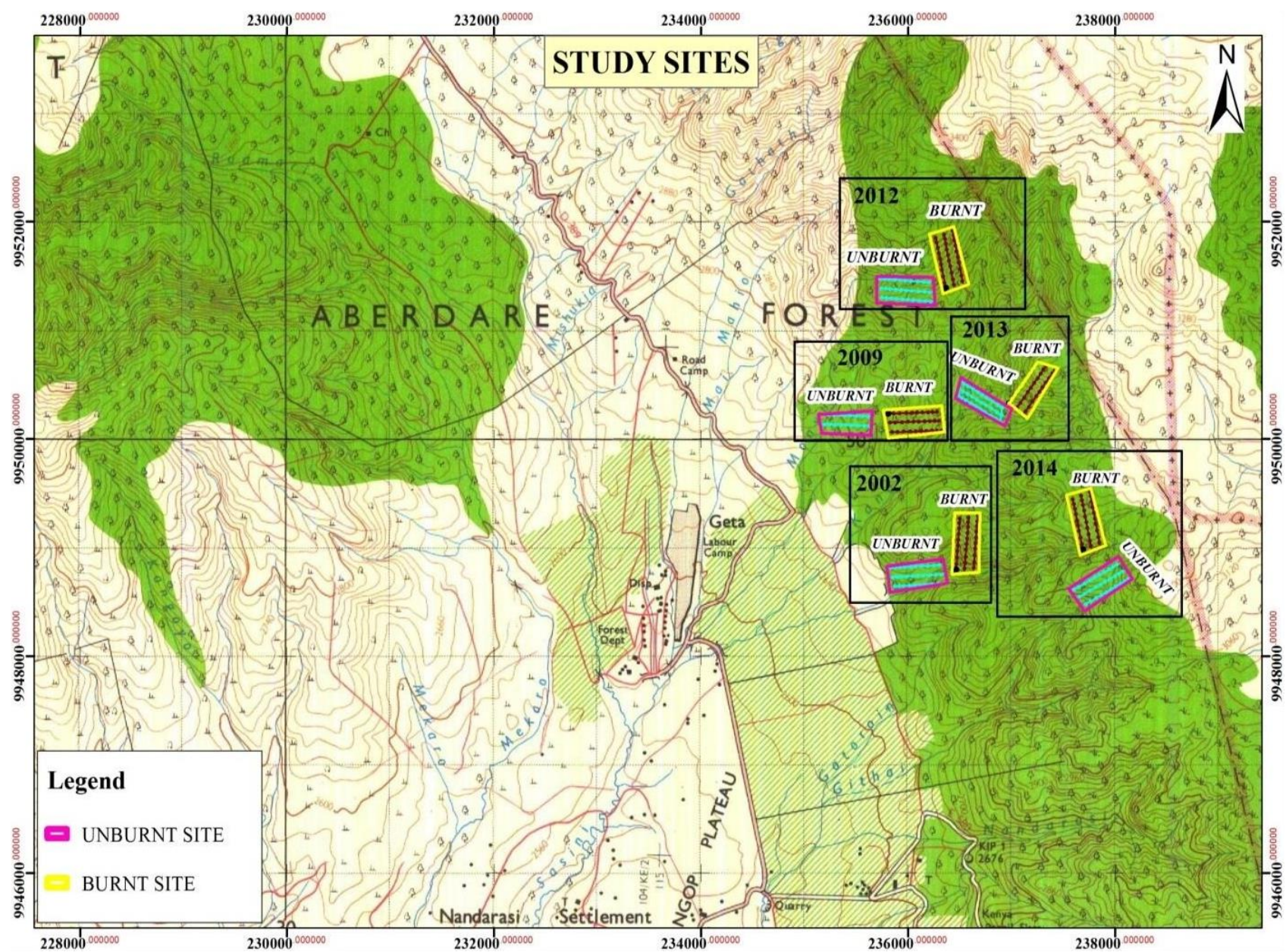

Figure 2. Map of the study sites in Western Aberdares, Kenya

Table 1. The key vegetation species at the Aberdare ranges, Kenya (Ng'ang'a 1990)

\begin{tabular}{|c|c|c|}
\hline Vegetation zone & Altitude in $\mathrm{m}$ asl and location & Key trees and shrub species \\
\hline Montane forest zone & / East & Cassipourea malosana, Ekebergia capensis, Teclea nobilis, \\
\hline & 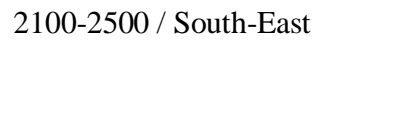 & $\begin{array}{l}\text { Calodendrum capense, Podocarpus latifolius, Nuxia congesta } \\
\text { Ocotea usambarensis, Macaranga kilimandscharica, Neoboutonia } \\
\text { macrocalyx, Tabernaemontana stapfiana, Prunus Africana }\end{array}$ \\
\hline Dry forest & $\begin{array}{l}\text { 1800-2400 / South-West } \\
\text { 2400-3300 / West } \\
\text { 2300-3200 / North, North-East }\end{array}$ & $\begin{array}{l}\text { Juniperus procera, Calodendrum capense, Teclea simplicifolia Juniperus } \\
\text { procera, Olea europaea (africana), Podocarpus } \\
\text { falcatus, Nuxia congesta }\end{array}$ \\
\hline Bamboo zone & $\begin{array}{l}\text { 2400-3000 / East, South-East } \\
\text { 2700-3300 / West }\end{array}$ & $\begin{array}{l}\text { Arundinaria alpina with scattered trees, including Podocarpus latifolius } \\
\text { and Nuxia congesta }\end{array}$ \\
\hline Hager & 2950-3500 (discontinuous) & Hagenia abyssinica, Hypericum revolutum, Rapanae melanophloeos \\
\hline Ericaceous zone & 2900-3560 (discontinuous) & $\begin{array}{l}\text { Erica excelsa, Erica trimera, Erica arborea, Cliffortia nitidula, } \\
\text { Helichrysum nandense, Stroebe kilimandscharica }\end{array}$ \\
\hline
\end{tabular}

Some parts of the upper forest zone fall within the Aberdare National Park. A high diversity of forest types characterizes the forest belt of the Aberdare Range due to the wide altitudinal range and the climatic differences between the slopes. The Aberdare Range is heavilyforested, much of them have been protected within the Aberdare National Park since its creation in 1950 (Ng'ang'a and Kamande 1990).

Vegetation zones and species distribution are characterized according to the different climatic zones and altitudes, mostly through variation in vegetation structure, cover, and composition. A total of 778 species, sub-species and varieties of vascular plants belonging to 421 genera and 128 families, have been documented in the Aberdare. 


\section{Animals in Aberdare Ranges}

The Aberdare Range forests host some threatened fauna species. The Jackson mongoose (Bdeugale jacksoni), endemic to Kenya's montane forests and the rarely seen golden cat (Felix aurata) are two threatened mammals. Other large threatened mammals of international conservation interest that occur in Aberdare forests are bongo (Tragelaphus euryceros), giant forest hog (Hylochoerus meinertzhageni), black rhino (Diceros bicornis), elephant (Loxodonta africana), leopard (Panthera pardus) and African hunting dog (Lycaon pictus). Also, the forest harbors bushbuck (Tragelaphus scriptus), mountain reedbuck (Redunca fulvorufula), waterbuck (Kobus ellipsiprymnus), suni (Neotragus moschatus), cape buffalo (Syncerus cafferNeotragus moschatus), side-striped jackel (Canis adustus), eland (Taurotragus oryx), and varieties of duikers and bushbabies. The forests are rich in primates, and the common ones include the black-andwhite colobus monkey (Colobus guereza), vervet monkey (Cercopithecus aethiops), sykes monkey (Cercopithecus mitis), and baboons (Papio anubis neumanni) (Waithaka 1994).

The Aberdare Range is internationally recognized as an Important Bird Area (IBA). The Range is a home for 52 of Kenya's 67 Afrotropical highland species and six of the eight restricted-range species in the Kenyan montane endemic bird areas. Over 270 species of birds have been documented in the Aberdares including the following globally threatened and restricted-range species: Sharpe's Longclaw, Aberdare Cisticola, Abbott's Starling, and Jackson's Widowbird. Regionally threatened species found in the Abedares include Cape Eagle Owl, African Crowned Eagle, and African Green Ibis. Jackson's Francolin, Hartlaub's Turaco and Bar-tailed Trogon are characteristic and spectacular birds of the Aberdare Range.

\section{Soils in Aberdare Ranges}

The grounds are polygenetic and occur in profoundly undulating topography, are subjected to intense leaching and have a low base saturation. The grounds are derived from massive lava flows, thick beds of volcanic tuffs and ash showers of geological formation. Soils are deeply weathered, highly porous, stone-free, free draining and support deep rooting associations of forest vegetation.

Soils on the upper eastern slopes of the Aberdare Ranges is highly fertile, being of basaltic origin. They are well-drained, usually very deep, dark reddish-brown, friable clays with a humid topsoil layer. On the western boundary of the Ranges, soils are also of medium to high inherent fertility, but are more variable and interspersed with poorer draining soils and lower productivity. The grounds of the moorlands are umbric andosols, derived from volcanic glass. The area is characterized by a high content of organic matter and is very porous.

The soils of the Northern Aberdare are rich in clay content $(82.7 \%)$ and consist almost exclusively of kaolinite. Red kaolinite soils are found on slopes, and dark grey, swelling montmorillonite (black cotton) grounds are located in areas of impeded drainage.

The soils of the southern area are characterized by dark surface horizons and are rich in organic matter. Their bulk density is low and includes Leptosols which are distinguished by a continuous coherent hard rock at very shallow depth, strong brown loams, eutrophic brown soils on volcanic ash and Gleysols which show hydromorphic properties within $50 \mathrm{~cm}$ of the surface and are found in valley bottoms.

\section{Methods}

The data were collected between September 2013 and March 2014. Both the wet season (September 2013 to December 2013) and dry season (January 2014 to March 2014) were covered. Five locations in the forest that had been burnt in 2002, 2009, 2012, 2013 and 2014 were selected. These sites were chosen since they were close to each other and had similar topography and vegetation. In every location, data were collected from both the burnt area and unburnt area that acted as a control. The unburnt regions were separated from burnt areas by buffers of at least $100 \mathrm{~m}$ to avoid fire effects.

\section{Woody vegetation sampling}

Point Centered Quarter (PCQ) sampling technique was utilized for the woody vegetation sampling. Three line transects (500 m long) were randomly set at each site, and sampling points along the transect lines were randomly set. Each sampling point was divided into four quarters using a perpendicular line placed at right angles to the line transect. Individual woody plants species closest to the point in each quarter were identified, and the points to individual plant distances were measured using a tape measure (Kevin 2007). The data that was recorded included: the nearest tree species to the sampling point to individual plant distance measured, the height of tree estimated measured using clinometer, diameter at breast height $(\mathrm{DBH})$ measured by Vernier calipers or a tape measure, and canopy cover measured by tape measure.

\section{Herbaceous plants sampling}

Quadrat sampling method was used (Cox 1990). Sampling was done on areas affected by fire in 2002, 2009, 2012, 2013 and 2014. Three line transects of $500 \mathrm{~m}$ long were randomly set in both burnt and unburnt areas at each site. Sampling points along the transect lines were randomly placed. Herbaceous layer species were sampled at each location using a quadrat measuring $0.25 \mathrm{~m}^{2}$. The percentage cover of the species was determined through estimation in all the quadrats, while the heights of the plants were measured using a tape measure.

\section{Animal census}

Direct foot count was done on all study sites to estimate the number of animals. The calculation was done once every week where the species name and the number of individuals were recorded. An indirect animal count was also be done by use of animal dung as described by Barnes, (1996). The indirect technique gave an index of abundance rather than a measure of animal density (Sutherland 1996). The length of fine dung may vary between habitat and between time periods, weather, dung decomposition rate, fiber content and the number of dung beetles and termites. Very fresh dung was marked, and during the second visit, 
the fresh dung scored in the previous visit was compared to the dung in the site and ignored any dung that looked more decayed. The indirect animal count gave a good indication of the study site use. The following equation was used to convert the number of dungs into the number of animals.

Number of animals $=\frac{\text { Number of dung }}{\text { Number of days between visits x defecation rate }}$

The species diversity was calculated using Shannon Weiner diversity index.

\section{Bird count}

Bird count was done once every week in the morning hours between 9.00 AM to 12.00 Noon. Point count was done along two transects in each study site. In every place, the bird count was done on the same day in both burnt and unburnt areas. The sampling points were chosen systematically on the transect after every $100 \mathrm{~m}$. In every sampling point, the birds were observed for 10 minutes by use of naked eyes and $8 \times 40$ binoculars. The bird species found and the heard calling was recorded. The distance between the observer and the birds and the activity of the bird were also recorded. Species diversity was calculated using Shannon Weiner diversity index.

\section{Soil sampling and $\mathrm{pH}$}

At every site, the burnt and unburnt sites (three sampling points at random) were selected such that their terrain was as similar as possible. Area for sampling was cleared of vegetation. The soil was dug up to $45 \mathrm{~cm}$ in depth. Samples were taken from $0-15 \mathrm{~cm}, 15-30 \mathrm{~cm}$ and 30 $45 \mathrm{~cm}$ at every sampling point for further analysis at the University of Nairobi soil laboratories. The grounds were air-dried, sieved through $2 \mathrm{~mm}$ screen and analyzed for physical and chemical properties. For each sample, $\mathrm{pH}$ was determined using distilled water in the soil to water ratio of 1: 2.5 (Peech 1965).

\section{Total nitrogen}

Total Nitrogen content was determined by Kjeldahl digestion method (Fleige et al. 1971). For $1 \mathrm{~g}$ of each soil sample, $3.5 \mathrm{~mL}$ of phenolic-sulphuric acid (36N) was added and left to stay for 15 minutes. Then, $0.5 \mathrm{~g}$ of Sodium thiosulphate was added and the samples left to rest for another 15 minutes. $0.5 \mathrm{~g}$ of potassium sulfate, $0.5 \mathrm{~g}$ of selenium reaction mixture and $3.5 \mathrm{~mL}$ of concentrated sulphuric acid were thereafter added. The samples were then digested using an electric Kjeltric digestion block. The digested samples were distilled after addition of $40 \mathrm{~mL}$ of $10 \mathrm{~N} \mathrm{NaOH}$ solution. A $1 \%$ boric acid solution captured the released nitrogen in the form of $\mathrm{NH}_{3}$ aqueous. The trapped $\mathrm{NH} 3$ was titrated with the $0.01 \mathrm{~N}$ solution of standard sulphuric acid. The results were expressed as total percentage nitrogen. The amount of nitrogen was calculated from the stoichiometric relationship that $1 \mathrm{~mL}$ of $0.01 \mathrm{~N}$ sulphuric acid used in the titration is equivalent to $0.14 \mathrm{mg}$ of nitrogen.

\section{Organic carbon}

The organic carbon was measured using the Walkley Black wet oxidation method (Black 1965). The soil samples were crushed and passed through a $0.6 \mathrm{~mm}$ sieve. Ten $\mathrm{mL}$ of dichromate solution was added into $1 \mathrm{~g}$ of the soil sample. Twenty $\mathrm{mL}$ sulphuric acid was added into the solution and mixed gently and the mixture was allowed to stand for 30 minutes. It was then diluted to $200 \mathrm{~mL}$ with deionized water. Ten $\mathrm{mL}$ of Phosphoric acid, $0.2 \mathrm{~g}$ ammonium fluoride, and ten drops of diphenylamine indicator were added.

The solution was titrated using a standard solution of ferrous sulfate. This procedure was repeated for all the soil samples, and the organic carbon content was calculated using the equation below:

$$
\% C=\frac{\text { Me of } \mathrm{K}_{2} \mathrm{Cr}_{2} \mathrm{O}_{7}-\mathrm{Me} \text { of } \mathrm{Fe}_{2} \mathrm{SO} \mathrm{SO}_{4} * 0.39}{\text { weight of soil }} * 100
$$

Where:

Me : Milliequivalents (normality * mLs of solution)

0.39 : Correction factor

\section{Potassium}

Potassium was extracted from air-dried soil samples by shaking the sample with $0.5 \mathrm{M}$ ammonium acetate acid solution for 30 minutes to effectively displace the potentially available potassium ions. The potassium content of the filtered extract was then determined using a Jenway PFP7 Flame Photometer.

\section{Phosphorous}

Phosphorus content was determined at an acidity of $0.20 \mathrm{M} \mathrm{H}_{2} \mathrm{SO} 4$ by reacting with ammonium molybdate using ascorbic acid which acts as a reductant in the presence of antimony using spectrophotometer (Mehlich 1984). Air-dried soil measuring $2 \mathrm{~g}$ was passed through < $2.0 \mathrm{~mm}$ into a $50 \mathrm{~mL}$ glass Erlenmeyer flask. $20.0 \mathrm{~mL}$ of Mehlich 3 extracting solution was added. The extraction flask was placed on a mechanical shaker for five minutes. The suspension was filtered immediately and the extract was collected in $40 \mathrm{~mL}$ plastic vials.

\section{Cation exchange capacity}

Following the ammonium extraction method, the soil samples were equilibrated with $1 \mathrm{~N}$ ammonium acetate of an adjusted $\mathrm{pH}$ of 7.0, then washed using four $50 \mathrm{~mL}$ portions of ethanol, or until no $\mathrm{NH} 4+$ ions were seen in the supernatant liquid after centrifuging as tested by Nessler's reagent.

The soil samples were then distilled using the Kjeldahl distilling unit after addition of magnesium oxide. Distillate (200 mL) was collected over $2 \%$ boric acid-indicator solution. The distillate was then titrated to the endpoint with $0.1 \mathrm{~N}$ standard $\mathrm{HCl}$ solution. One $\mathrm{mL}$ of $0.1 \mathrm{~N} \mathrm{HCl}$ used in titration is equal to 1 milliequivalent per $100 \mathrm{~g}$ of soil for an original soil sample site of $10 \mathrm{~g}$. The amount was expressed in milliequivalents per $100 \mathrm{~g}$ of soil (Black 1965). 


\section{Data analysis}

Species diversity of the vegetation and wildlife was estimated using Shannon Weiner diversity index:

$$
\begin{aligned}
& \mathrm{H}^{\prime}=-\Sigma P i \times \log P i \\
& \mathrm{Pi}=\frac{n i}{N}
\end{aligned}
$$

Where:

$n i$ is number of individuals of species $i$

$N$ is total number of species

The data were analyzed using SPSS version 20 and Microsoft Excel spreadsheet statistical packages. For the woody species diversity, T-test was used to examine whether there was a difference between the burnt sites and unburnt sites. Univariate Analysis of Variance (ANOVA) was used to determine whether there were differences in the DBHs, heights, and canopies between the burnt and unburnt sites. ANOVA was also used to determine whether there were differences in DBHs, heights, and canopies among the five burnt sites.

For the herbaceous vegetation, T-test was applied to determine whether there was a difference in species diversity between the burnt sites and unburnt sites. Percentage cover of the herbaceous vegetation was first transformed utilizing arcsin transformation before it was analyzed. ANOVA was used to determine the differences in cover, number of individual plants and heights between the burnt sites and unburnt sites and among the five burnt sites. The possible sources of variances where there were more than two groups were determined using the Post Hoc method. The average of individuals was separated by the LSD method.

A t-test was also used to determine whether there was a difference in wildlife species diversity. For the soil properties, ANOVA was used to determine if there was any difference between the burnt and unburnt sites. ANOVA was also used to assess differences among the three depth levels. It was also used to determine differences in the soil properties among the five burnt sites.

\section{RESULTS AND DISCUSSION}

\section{Woody species diversity}

The result demonstrates that fires did not affect the species diversity of the woody plants as the calculated species diversity index did not show any significant difference between the species diversity in the burnt sites and the unburnt sites (Table 2). The mean species diversity of all burnt places was $2.045 \pm 0.102$, and that of all unburnt sites was $2.040 \pm 0.102$.

\section{Community structure of woody plants}

A total of 7 different woody plant species belonging to 7 different families were counted. The woody species found in all the sites are shown in Table 3.
$D B H$

The mean DBH of all the woody plant species at the burnt sites was less than that at the unburnt sites. The mean DBH of the burnt sites increased with the years after burning with the one of 2014 being the smallest at $0.34 \pm 0.1 \mathrm{~m}$ and that of 2009 is the highest at $0.60 \pm 0.2 \mathrm{~m}$. Although time had caused recovery of the woody plant species in burnt sites, there was no burnt site whose DBH had recovered to be equal or more than that of the unburnt site. The DBH of all species is shown in Figure 3.

There was a significant difference in the DBH of all species between all burnt sites and all unburnt sites with the species in the unburnt locations having a higher mean $\mathrm{DBH}$ of $0.63 \pm 0.026 \mathrm{~m}$ and those in the burnt locations having a mean DBH of $0.49 \pm 0.026 \mathrm{~m}$. There was also a significant difference in the DBH between all the five burnt sites with the maximum mean difference being between 2002 and 2014 and the minimum mean difference being between 2002 and 2009.

\section{Height}

The heights of the woody plant species were smaller in the burnt sites than those in the unburnt sites. The average height of the burnt sites increased with the years after burning with the one of 2014 being the shortest at $21 \pm 5.2 \mathrm{~m}$ and that of 2002 is the tallest at $24 \pm 5.1 \mathrm{~m}$. There is no burnt site whose height had recovered to be equal or more than that of the unburnt site. Figure 4 listed all the heights of all woody species. There was no significant difference in the heights among all burnt sites and all unburnt sites and between all the burnt sites at different years.

\section{Canopy}

The mean canopies of all the burnt sites were smaller than the unburnt sites. The mean canopies of the burnt sites increased with the years after burning with the one of 2014 being the lowest at $1.5 \pm 0.4 \mathrm{~m}$ and that of 2002 is the highest at $4.7 \pm 1.0 \mathrm{~m}$. There is no burnt site whose the canopy had recovered to be equal or more than that of the unburnt site. The values of the canopy of all species are shown in Figure 5.

Table 2. The species diversity $\left(\mathrm{H}^{\prime}\right)$ of the woody vegetation in burnt and unburnt sites

\begin{tabular}{lll}
\hline Year & Burnt $\left(h^{\prime}\right)$ & Unburnt $\left(h^{\prime}\right)$ \\
\hline 2002 & 1.786 & 1.778 \\
2009 & 2.341 & 2.362 \\
2012 & 1.894 & 1.848 \\
2013 & 2.018 & 2.114 \\
2014 & 2.185 & 2.098 \\
\hline
\end{tabular}

Table 3. The woody plant species and family found in all the sites

\begin{tabular}{llcc}
\hline \multicolumn{1}{c}{ Family } & \multicolumn{1}{c}{ Species } & $\begin{array}{c}\text { Burnt } \\
\text { sites }\end{array}$ & $\begin{array}{c}\text { Unburnt } \\
\text { sites }\end{array}$ \\
\hline Bignoniaceae & Markhamia lutea & 101 & 94 \\
Canellaceae & Warburgia ugandensis & 113 & 95 \\
Cupressaceae & Juniperus procera & 62 & 85 \\
Lauraceae & Ocotea usambarensis & 95 & 86 \\
Oleaceae & Olea africana & 105 & 97 \\
Podocarpaceae & Podocarpus falcatus & 91 & 100 \\
Stilbaceae & Nuxia congesta & 36 & 39 \\
\hline
\end{tabular}




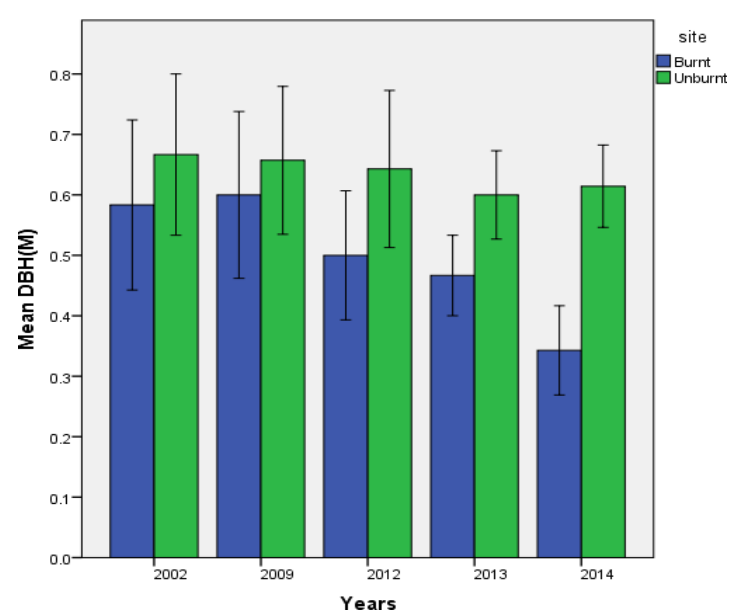

Figure 3. The mean DBH of the woody species in all the sites

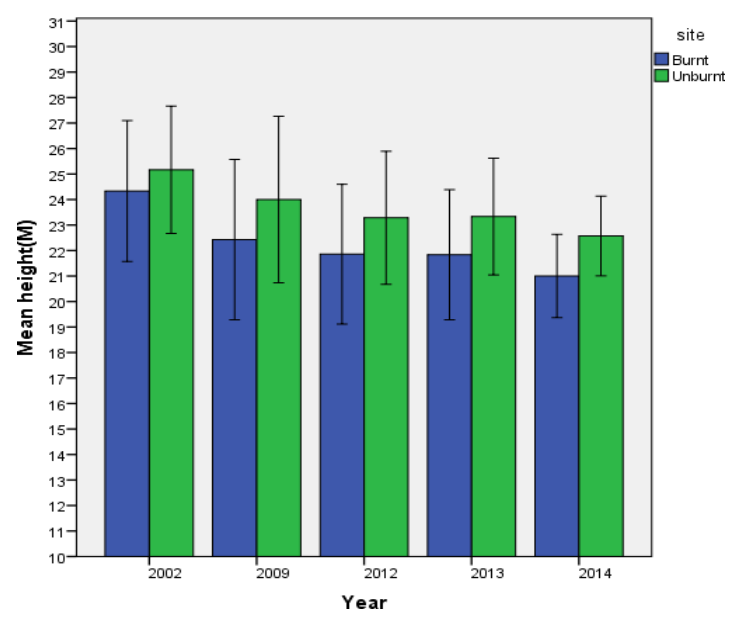

Figure 4. The average height of the trees in all the burnt and unburnt sites

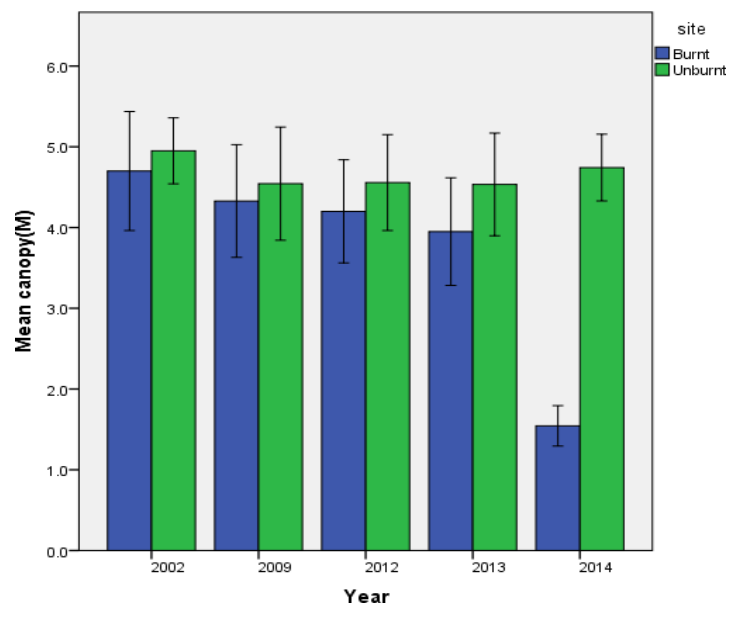

Figure 5. The mean canopy of trees in all the sites

There was a significant difference in the canopy between all burnt sites and unburnt sites $(\mathrm{F} 1,64=12.467$; $\mathrm{P}<0.05)$. There was also a substantial difference in the canopy between all the five burnt sites (F4, $28=17.418$;
$\mathrm{P}<0.05)$ with the maximum mean difference being between 2002 and 2014 of $3.157 \pm 0.44 \mathrm{~m}$ and the minimum mean difference being at 2002 and 2009 of $0.371 \pm 0.44 \mathrm{~m}$.

\section{Herbaceous species diversity}

Fire markedly reduced species diversity of the herbaceous plants immediately after it occurred. However, the species diversity quickly recovered within one year and got higher than the unburnt sites as plants regenerated after the fires. The place that had been burnt less than a year ago, i.e., in 2014, is the only one that had lesser species diversity than the unburnt site. Within a year, the herbaceous vegetation had already recovered and was more in the places that had been burnt. The species diversity of the herbaceous plant of all sites is shown in Table 4.

\section{Community structure of herbaceous species}

In all the burnt sites, a total of 39 species were counted while in all unburnt places, a total of 22 species were counted. Only seventeen species were found in the burnt sites. All the species found in the unburnt places were also found in the burnt locations. Table 5 is a list of the herbaceous plant species that were found in the burnt sites and not found in the unburnt locations.

Table 4. The species diversity $\left(\mathrm{H}^{\prime}\right)$ of the herbaceous vegetation in burnt and unburnt sites.

\begin{tabular}{lcc}
\hline Year & Burnt $\left(\mathrm{H}^{\prime}\right)$ & Unburnt $\left(\mathrm{H}^{\prime}\right)$ \\
\hline 2002 & 2.441 & 1.682 \\
2009 & 2.469 & 1.716 \\
2012 & 2.369 & 1.837 \\
2013 & 2.298 & 1.603 \\
2014 & 0.950 & 1.737 \\
\hline
\end{tabular}

Table 5. The herbaceous species and family found in the burnt locations and not found in the unburnt locations

\begin{tabular}{ll}
\hline Family & Species \\
\hline Apiaceae & Ferula communis \\
Apocynaceae & Gomphocarpus stenophyllus \\
Asteraceae & Cardius keniensis \\
& Crepis aurea \\
& Dichrocephala chrysanthemifolia \\
& Gnaphalium purpureum \\
Fabacea & Crotalaria paniculata \\
& Rhynchosia minima \\
& Trifolium cryptopodium \\
& Trifolium tembense \\
& Adenocarous manii \\
Lamiaceae & Leucas venulosa \\
Poaceae & Oplismenus compositus \\
Ranunculaceae & Delphinium macrocentron \\
Rhamnaceae & Rhamnus prinoides \\
Rosaceae & Alchemilla gracilipes \\
Rubiaceae & Pentas lanceolata \\
\hline
\end{tabular}




\section{Cover}

The site burnt on 2104 was the only one that had a lower mean percentage cover compared to its unburnt places. All the other burnt places had more percentage cover than their unburnt sites as the herbaceous vegetation in those burnt sites had already regenerated and exceeded the unburnt sites. It took only one year for the herbaceous vegetation to restore its cover increase. The percentage cover of all the species found in every place is shown in Figure 6.

After Arcsin transformation of the percentage cover, there was a significant difference between the percentage cover of the burnt sites and the unburnt sites with the burnt sites having a higher mean cover $8.39 \pm 0.94 \%$ than the unburnt sites which had a mean cover of $5.47 \pm 0.84 \%$.

There was also a significant difference in the cover between all the burnt sites in the different years $(\mathrm{F} 4$, $73=8.309 ; \mathrm{P}<0.05)$. The most considerable mean difference was between the year 2014 and 2002 which was $20.23 \pm$ $4.09 \%$, and the smallest mean difference was between the year 2009 and 2002 which was $1.42 \pm 2.13 \%$.

\section{Number of individual plants}

The location burnt in 2014 was the only one showing a lower number of herbaceous plants compared to the unburnt places (Figure 7). All the other burnt places had a higher number of herbaceous plants than the unburnt sites as fire led to regeneration in a year's time leading to a higher number of individuals in the burnt places.

There was a significant difference between the number of individuals in the burnt sites and the unburnt sites with the burnt sites having a higher mean number of $58.42 \pm 8.37$ plants than the unburnt places which had a mean number of $35.83 \pm 7.53$ plants.

There was also a significant difference in the number of individuals between all the burnt sites in the different years $(\mathrm{F} 4,73=3.101 ; \mathrm{P}<0.05)$. The maximum mean difference was between the year 2014 and 2002 which was $58.23 \pm$ 20.97 plants and the minimum mean difference was between the year 2009 and 2002 which was $16.48 \pm 18.34$ plants.

\section{Height}

The site burnt in 2014 was solely the one that had a smaller mean height of herbaceous plants compared to the unburnt sites. All the other burnt sites had a bigger mean height of herbaceous plants than the unburnt sites. The height of every species is displayed in Figure 8.

There was a significant difference between the height of the herbaceous plants with the burnt sites having a higher mean height of $81.56 \pm 5.05 \mathrm{~cm}$ than the unburnt sites which had an average number of $61.85 \pm 4.47 \mathrm{~cm}$.

There was also a significant difference in the height of the plants between all the burnt sites in the different years. The maximum mean difference was between the year 2014 and 2002 which was $41.34 \pm 14.19 \mathrm{~cm}$, and the minimum mean difference was between the year 2009 and 2002 which was $10.74 \pm 13.04 \mathrm{~cm}$.

\section{Animals}

Nine different species from 5 families were counted in all the sites (Figure 9). There were no animals that were recorded in the place that was burnt in 2014. Only the sites that had been burnt in 2014 and 2013 had fewer animals than their corresponding unburnt locations. All the other burnt places had more animals compared to their similar unburnt sites. The site that was burnt in 2012 had the highest number of animals which was 132. Amongst the unburnt sites, 2014 had the highest number with 86 .

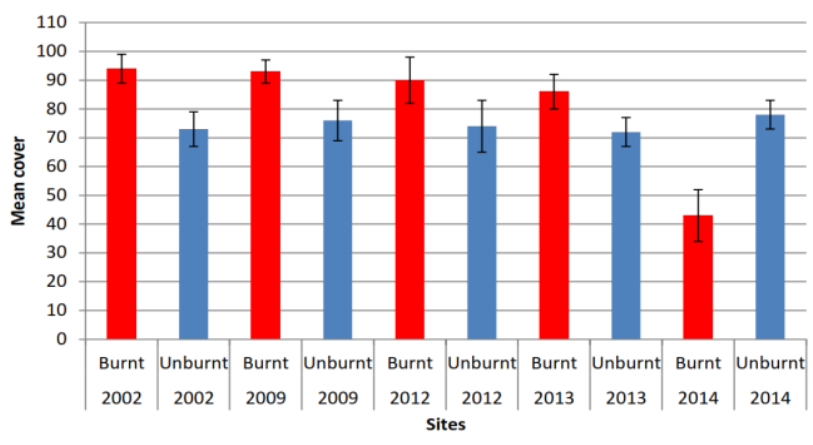

Figure 6. The mean percentage cover of the herbaceous vegetation in all sites

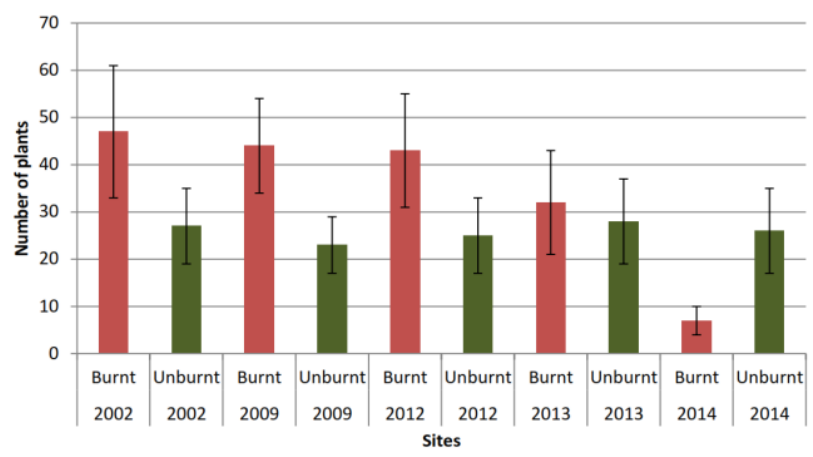

Figure 7. The mean number of plants found in all sites

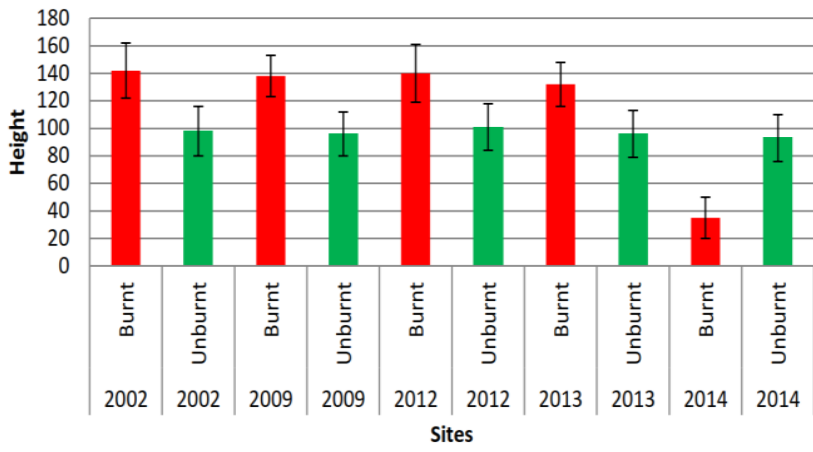

Figure 8. The mean height $(\mathrm{cm})$ of the species found in all sites 
Animals species diversity

Table 6 shows no animal was observed on the site that had recently been burnt (less than two weeks after the fire2014). In the place that had been burnt one year ago, the species diversity of the animals was less than the unburnt site. In all the other areas that had been burnt more than one year ago, the species diversity of the animals was more than in their corresponding unburnt sites.

\section{Birds}

Thirty-four species belonging to 13 different families were counted in all sites. All the unburnt sites had a higher number of birds than the unburnt sites (Figure 10).

The species diversity of the birds is shown in Table 7. In all sites, the diversity was higher which had been burnt more than a year ago than in the unburnt sites. Only the sites that had been burnt less than a year ago had less species diversity than the unburnt sites because there was more vegetation in the burnt sites that provided habitat and food for the birds.

\section{Soil properties}

$$
p H
$$

The mean $\mathrm{pH}$ values of soils from both the burnt sites and unburnt sites at the three levels of depth are displayed in Figure 11. The soils were acidic as their $\mathrm{pH}$ ranged from 3.4 in 2014 unburnt site to 6.5 in the site which was burnt. At $0-15 \mathrm{~cm}$ depth, the mean $\mathrm{pH}$ of the burnt sites was higher in the sites burnt in 2014, 2013, 2012 and 2009. The locations that were burnt in 2002 were the only that had a lower $\mathrm{pH}$ compared to the unburnt site. The mean $\mathrm{pH}$ at 0 $15 \mathrm{~cm}$ of the burnt and unburnt sites was $5.28 \pm 0.68$ and $4.26 \pm 0.57$ respectively. There was a significant difference in $\mathrm{pH}$ of the soil at the $0-15 \mathrm{~cm}$ depth between burnt sites and unburnt sites (t 0.05 (1), 14=3.619; $\mathrm{P}<0.05$ ).

At $15-30 \mathrm{~cm}$, the mean $\mathrm{pH}$ of all the burnt sites was higher than the unburnt sites. The mean $\mathrm{pH}$ of the burnt sites at this depth was $4.99 \pm 0.28$, and that of the unburnt sites was $4.68 \pm 0.27$. The $\mathrm{pH}$ at a depth of $15-30 \mathrm{~cm}$ had a significant difference between the burnt sites and unburnt sites (t 0.05 (1), 14=3.961; $\mathrm{P}<0.05$ ).

At $30-45 \mathrm{~cm}$, the mean $\mathrm{pH}$ of the burnt sites was higher than unburnt sites apart from the sites burnt in 2002 and 2009. The mean $\mathrm{pH}$ of the burnt sites was $4.85 \pm 0.27$ while that of the unburnt sites was $4.82 \pm 0.32$. The $\mathrm{pH}$ at a depth of $30-45 \mathrm{~cm}$ did not have a significant difference between the burnt and the unburnt sites ( 0.05 (1), 14=0.349; $\mathrm{P}>0.05)$.

Table 6. The species diversity $\left(\mathrm{H}^{\prime}\right)$ of animals in burnt and unburnt sites

\begin{tabular}{lll}
\hline Year & Burnt $\left(\mathbf{H}^{\prime}\right)$ & Unburnt $\left(\mathbf{H}^{\prime}\right)$ \\
\hline 2002 & 1.6771 & 1.5924 \\
2009 & 1.6315 & 1.5997 \\
2012 & 1.9407 & 1.7144 \\
2013 & 1.2613 & 1.7926 \\
2014 & 0 & 1.8623 \\
\hline
\end{tabular}

Table 7. The species diversity $\left(\mathrm{H}^{\prime}\right)$ of birds observed burnt and unburnt sites

\begin{tabular}{lll}
\hline Site & Burnt $\left(\mathbf{H}^{\prime}\right)$ & Unburnt $\left(\mathbf{H}^{\prime}\right)$ \\
\hline 2002 & 2.7352 & 2.6989 \\
2009 & 2.8815 & 2.8291 \\
2012 & 2.7871 & 2.6314 \\
2013 & 2.1923 & 2.2248 \\
2014 & 2.2036 & 2.6927 \\
\hline
\end{tabular}

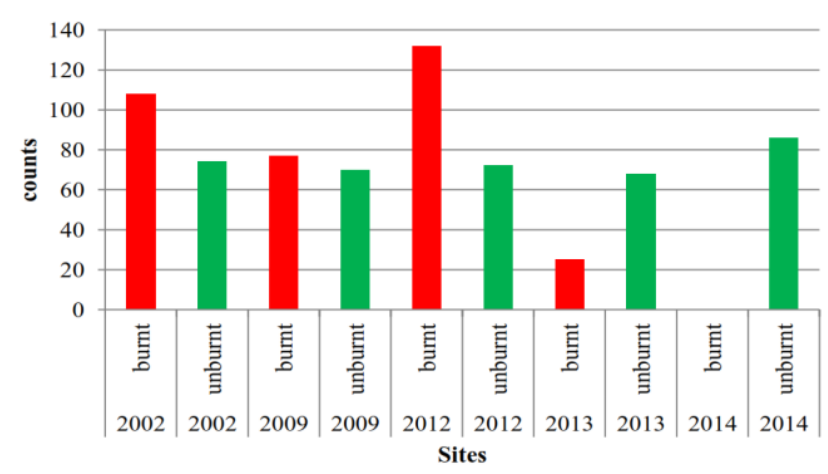

Figure 9. The total number of animals found in all the burnt and unburnt sites

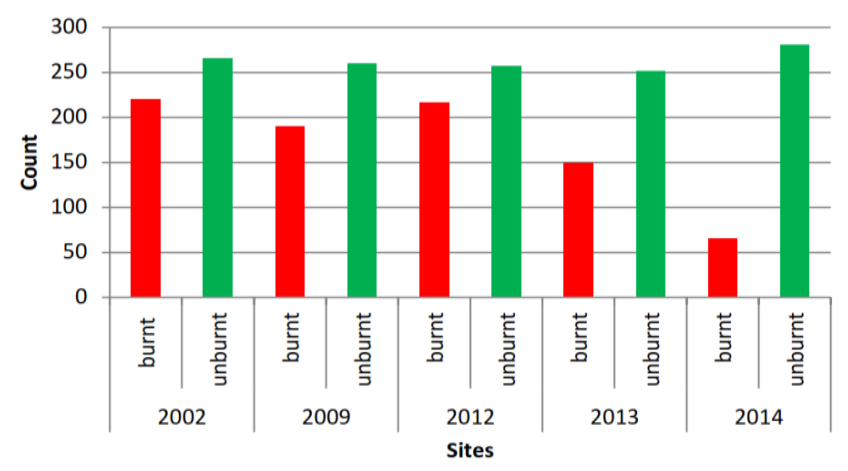

Figure 10. The total count of birds in all burnt and unburnt sites.

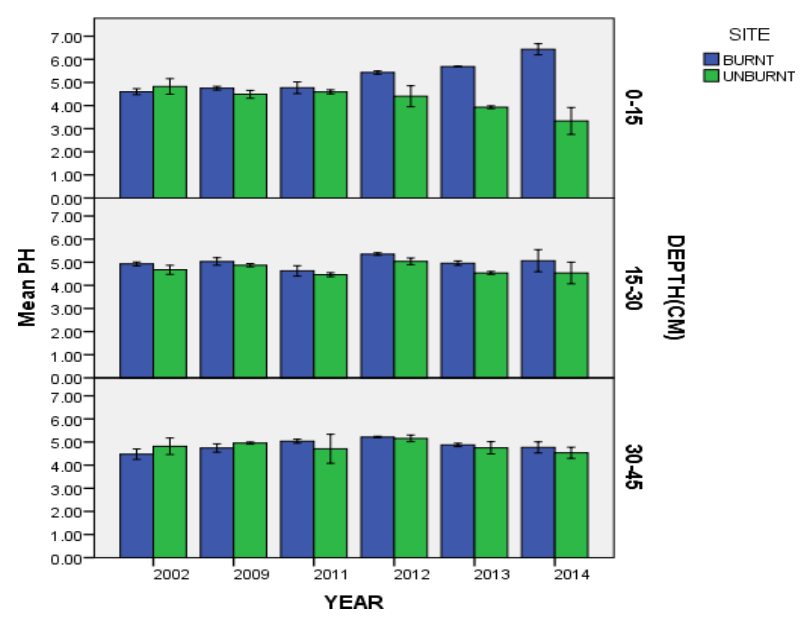

Figure 11. The $\mathrm{pH}$ of soils from both the burnt sites and unburnt sites at the three levels of depth 


\section{Nitrogen}

Data for percent nitrogen is shown in Figure 12. The data indicate that at $0-15 \mathrm{~cm}$ deep, the amount of nitrogen in the soils from the burnt sites was lower than in soils from unburnt sites in the sites burnt in 2014, 2013 and 2012. However, on the sites that were burnt in 2009 and 2002, the soils had slightly higher nitrogen content compared to the unburnt site. The mean nitrogen at 0-15 $\mathrm{cm}$ of the burnt sites was $0.68 \pm 0.19 \%$, and that of the unburnt sites was $1.10 \pm 0.66 \%$. There was a significant difference in soil nitrogen at the $0-15 \mathrm{~cm}$ depth between burnt sites and unburnt sites $(\mathrm{F} 1,34=5.353 ; \mathrm{P}<0.05)$.

At $15-30 \mathrm{~cm}$, the mean nitrogen of all the burnt sites was lower than the unburnt sites apart from the site burnt in 2014 where the mean nitrogen was higher in the burnt site than in the unburnt site. The mean nitrogen of the burnt sites at this depth was $0.58 \pm 0.21 \%$, and that of the unburnt sites was $0.70 \pm 0.17 \%$. At this depth, nitrogen amount was comparable between burnt and unburnt sites.

At $30-45 \mathrm{~cm}$, the mean nitrogen of the burnt sites was lower than unburnt sites apart from the sites burnt in 2014 . The mean nitrogen of the burnt sites was $0.45 \pm 0.26 \%$ while that of the unburnt sites was $0.67 \pm 0.26 \%$. The nitrogen at a depth of $30-45 \mathrm{~cm}$ had a significant difference between the burnt and the unburnt sites $(\mathrm{F} 1,34=29.55$; $\mathrm{P}<0.05)$.

Univariate tests of nitrogen between depths showed that there was a significant difference between the three levels of depths $(\mathrm{F} 2,51=7.819 ; \mathrm{P}<0.05)$. After post hoc tests, the significant difference was between $0-15 \mathrm{~cm}$ and $30-45 \mathrm{~cm}$ and also between $0-15 \mathrm{~cm}$ and $15-30 \mathrm{~cm}$. Between $15-30 \mathrm{~cm}$ and $30-45 \mathrm{~cm}$, the mean difference was 0.14 and $\mathrm{P}>0.05$ meaning there was no significant difference.

The nitrogen level between the sites burnt at different years was significantly different. The maximum mean difference was observed between 2002 and 2014, and the minimum mean difference was between 2002 and 2012 .

\section{Organic carbon}

The mean organic carbon values in the soils from all the sites are shown in Figure 13. The data indicate that at 0-15 $\mathrm{cm}$ deep, the mean organic carbon of the burnt sites was higher in the sites burnt in 2014, 2013 and 2012 than in their unburnt sites. The sites that were burnt in both 2009 and 2002 had a lower mean organic carbon compared to the unburnt site. The mean organic carbon at $0-15 \mathrm{~cm}$ of the burnt sites was $7.05 \pm 0.93$, and that of the unburnt sites was $6.07 \pm 1.59$. At a depth of $0-15 \mathrm{~cm}$, there was a significant difference between the amount of organic carbon in the burnt sites and unburnt sites $(\mathrm{F} 1,34=30.085 ; \mathrm{P}<0.05)$.

At $15-30 \mathrm{~cm}$, the mean organic carbon of the sites burnt in 2014, 2013 and 2012 was higher than the unburnt sites. The sites burnt in 2009 and 2002 had a lower mean organic carbon than in the unburnt sites. The mean organic carbon of the burnt sites at this depth was $6.07 \pm 1.26 \%$, and that of the unburnt sites was $5.60 \pm 1.52 \%$. At this depth, the amount of organic carbon between the burnt sites and the unburnt sites was relatively the same.

At $30-45 \mathrm{~cm}$, the mean organic carbon of the sites burnt in 2014 and 2012 was higher than the unburnt sites. The sites burnt in 2009, 2002 and 2013 had a lower mean organic carbon than in the unburnt sites. The mean organic carbon of the burnt sites was $5.19 \pm 1.94 \%$ while that of the unburnt sites was $5.27 \pm 1.31 \%$. The organic carbon at a depth of $30-45 \mathrm{~cm}$ had no significant difference in the amount of organic carbon between the burnt sites and the unburnt sites $(\mathrm{F} 1,34=0.141 ; \mathrm{P}>0.05)$.

Univariate tests of organic carbon between depths showed that there was a significant difference between the three levels of depths $(\mathrm{F} 2,51=6.374 ; \mathrm{P}<0.05)$. After post hoc tests, the main difference was between $0-15 \mathrm{~cm}$ and 30 $45 \mathrm{~cm}$ as well as between $0-15 \mathrm{~cm}$ and $15-30 \mathrm{~cm}$. On the other hand, there was no significant difference between 15$30 \mathrm{~cm}$ and $30-45 \mathrm{~cm}$ depth.

There was a significant difference in the organic carbon between the sites burnt at different years. The maximum mean difference was between 2002 and 2014 which was $1.76 \pm 0.69 \%$, and the least mean difference was between 2002 and 2013 which was $0.54 \pm 0.69 \%$.

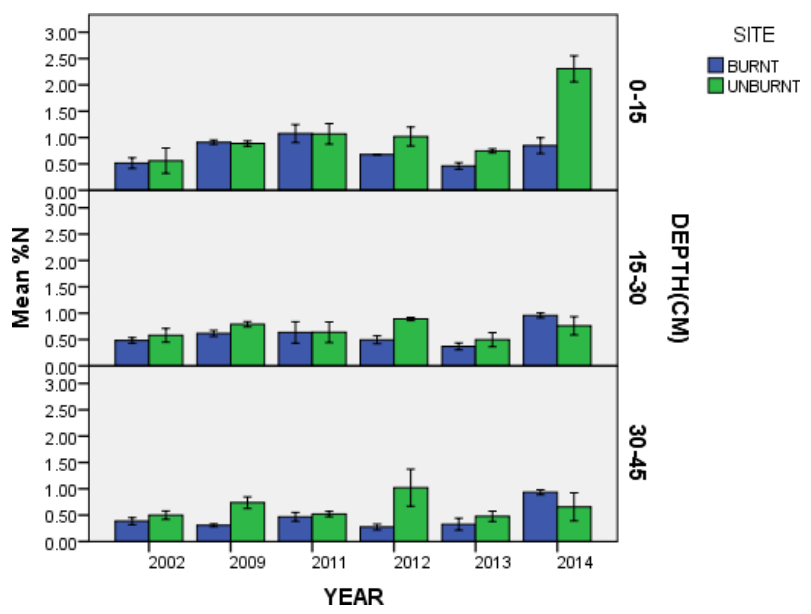

Figure 12. The nitrogen (\%) of soils from all burnt and unburnt sites at the three depth levels

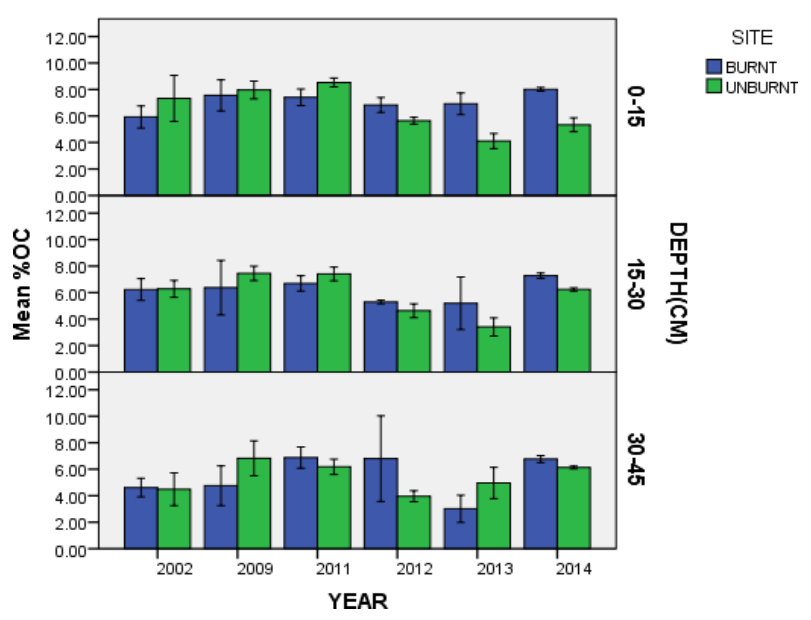

Figure 13. The organic carbon of soils from all burnt and unburnt sites at different depths 


\section{Potassium}

The average values of the potassium in the soils from all the sites are shown in Figure 14. The data demonstrate that at $0-15 \mathrm{~cm}$ deep, the mean potassium was higher in all the burnt sites than in their unburnt sites apart from the site burnt in 2009 . The mean potassium at $0-15 \mathrm{~cm}$ of the burnt sites was $2.68 \pm 1.78$ and that of the unburnt sites was $1.14 \pm 0.61$.

At $15-30 \mathrm{~cm}$, the mean potassium of all the burnt sites was higher than the unburnt sites. The mean potassium of the burnt sites at this depth was $1.58 \pm 0.98 \mathrm{Cmol} / \mathrm{kg}$, and that of the unburnt sites was $1.21 \pm 0.81 \mathrm{Cmol} / \mathrm{kg}$. At 15 $30 \mathrm{~cm}$, there was no significant difference in the amount of potassium between the burnt sites and the unburnt sites (F1 $34=0.766 ; \mathrm{P}>0.05)$.

At $30-45 \mathrm{~cm}$, the mean potassium of the sites burnt in 2014, 2012 and 2002 was higher than the unburnt sites. The sites burnt in 2013 and 2009 had lower mean potassium than that of unburnt sites. The mean potassium of the burnt sites was $1.31 \pm 0.97 \mathrm{Cmol} / \mathrm{kg}$ while that of the unburnt sites was $1.03 \pm 0.61 \mathrm{Cmol} / \mathrm{kg}$. At $30-45 \mathrm{~cm}$ depth, there was also no significant difference in the amount of potassium between the burnt sites and the unburnt sites $(\mathrm{F} 1,34=1.659$; $\mathrm{P}>0.05$ ).

Univariate tests of potassium between depths showed that there was a significant difference between the three levels of depths $(\mathrm{F} 2,51=5.951 ; \mathrm{P}<0.05)$. After post hoc tests, the main difference was between $0-15 \mathrm{~cm}$ and 30 $45 \mathrm{~cm}$ where the mean difference was $1.32 \mathrm{Cmol} / \mathrm{kg}$ and $\mathrm{P}<0.05$. Between $0-15 \mathrm{~cm}$ and $15-30 \mathrm{~cm}$, there was also a significant difference. However, between $15-30 \mathrm{~cm}$ and 30 $45 \mathrm{~cm}$, there was no significant difference.

There was a significant difference in the potassium between the sites burnt at different years. The maximum mean difference was between 2002 and 2014 which was $2.71 \pm 0.43 \mathrm{Cmol} / \mathrm{kg}$, and the minimum means difference was between 2002 and 2009 which was $0.46 \pm 0.43$ $\mathrm{Cmol} / \mathrm{kg}$.

\section{Phosphorous}

The mean phosphorous values in the soils from all the sites are shown in Figure 15. The data shows that at 0-15 $\mathrm{cm}$ depth, the mean phosphorous was lower in all the burnt sites than in their unburnt sites apart from the site burnt in 2009. The mean phosphorous at $0-15 \mathrm{~cm}$ of the burnt sites was $8.26 \pm 2.49 \mathrm{ppm}$ and that of the unburnt sites was $13.32 \pm 3.83 \mathrm{ppm}$. The amount of phosphorous was significantly different between the burnt sites and unburnt sites at this depth.

At $15-30 \mathrm{~cm}$, the mean phosphorous was lower in all the burnt sites than in their unburnt sites apart from the site burnt in 2009. The mean phosphorous at $15-30 \mathrm{~cm}$ of the burnt sites was $7.59 \pm 3.86$ and that of the unburnt sites was $10.11 \pm 2.89 \mathrm{ppm}$. There was no significant difference in the amount of phosphorous between the burnt sites and the unburnt sites $(\mathrm{F} 1,34=3.55 ; \mathrm{P}>0.05)$.

At $30-45 \mathrm{~cm}$, the mean phosphorous of the sites burnt in 2014, 2012 and 2002 was lower than the unburnt sites. The areas burnt in 2013 and 2009 had higher mean phosphorous than in the unburnt sites. The mean phosphorous of the burnt sites was $8.49 \pm 3.46 \mathrm{ppm}$ while that of the unburnt sites was $9.01 \pm 1.72 \mathrm{ppm}$.

Univariate tests of phosphorous between depths showed that there was no significant difference between the three levels of depths. There was a significant difference in the phosphorous between the sites burnt at different years. The maximum mean difference was between 2002 and 2014 which was $5.93 \pm 0.73 \mathrm{ppm}$, and the minimum mean difference was between 2002 and 2009 which was $0.14 \pm 0.73 \mathrm{ppm}$.

\section{Cation Exchange Capacity (CEC)}

The mean CEC values in the soils from all the sites are shown in Figure 16. The data shows that at $0-15 \mathrm{~cm}$ deep, the mean CEC was higher in all the burnt sites than in their unburnt sites apart from the site burnt in 2002.

At $15-30 \mathrm{~cm}$, the mean CEC was higher in all the burnt sites than in their unburnt sites apart from the site burnt in 2002. The mean CEC at $15-30 \mathrm{~cm}$ of the burnt sites was $20.16 \pm 2.78 \mathrm{~mol} / \mathrm{kg}$, and that of the unburnt sites was $18.34 \pm 3.41 \mathrm{~mol} / \mathrm{kg}$. The CEC at a depth of $15-30 \mathrm{~cm}$ did not have a significant difference between the burnt sites and unburnt sites $(\mathrm{F} 1,34=1.523 ; \mathrm{P}>0.05)$.

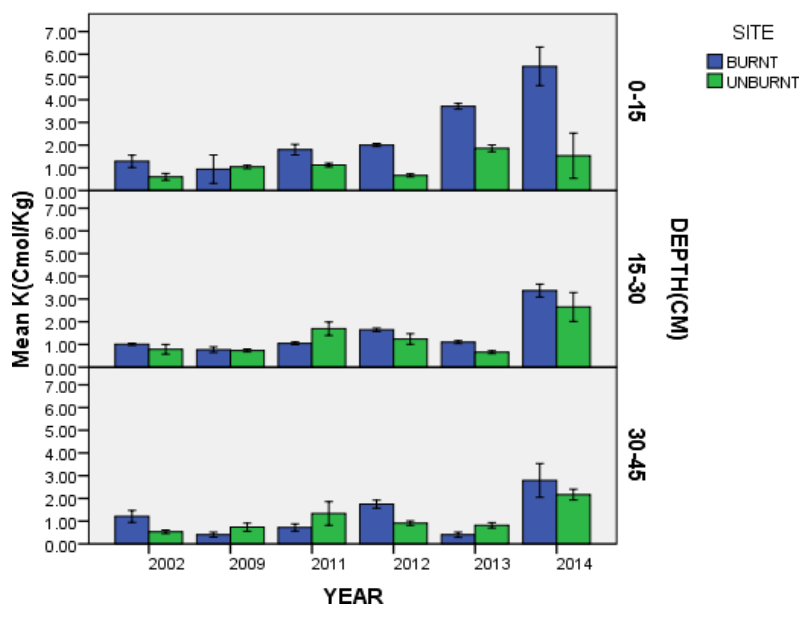

Figure 14. The potassium of soils from all the burnt and unburnt sites at different depths

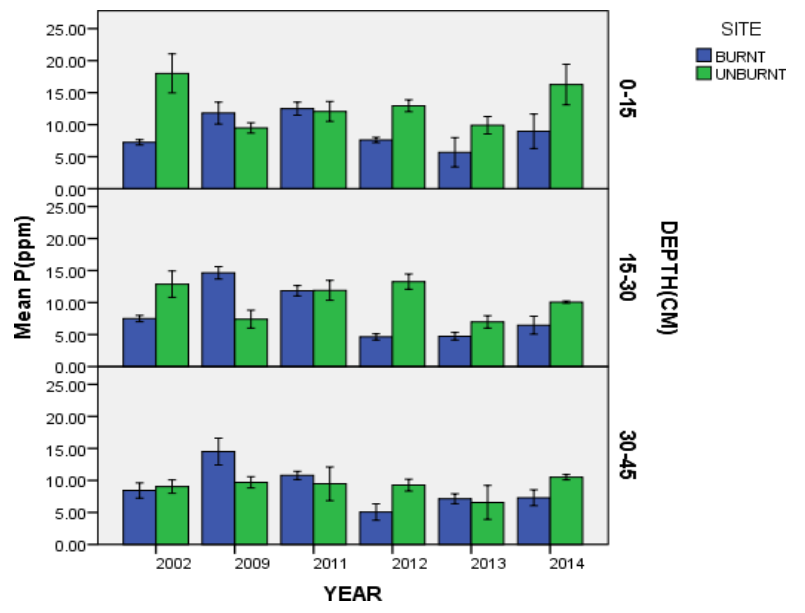

Figure 15. The phosphorous of soils observed in all the burnt and unburnt sites at different depths 


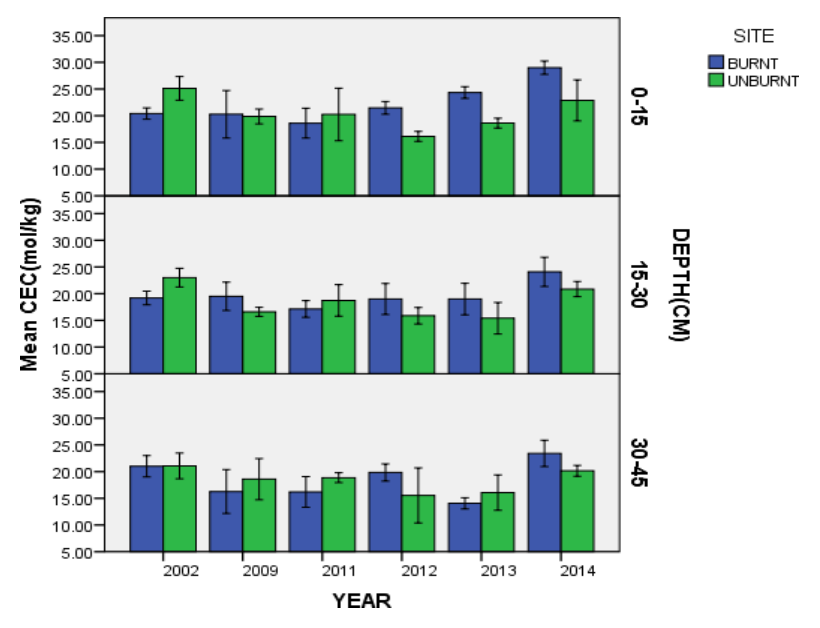

Figure 16. The CEC of soils from all the burnt and unburnt sites at different depths

At $30-45 \mathrm{~cm}$, the mean CEC of the sites burnt in 2014, 2012 and 2002 was higher than the unburnt sites. The sites burnt in 2013 and 2009 had lower mean CEC than in the unburnt sites. The mean CEC of the burnt sites was $18.91 \pm 3.90 \mathrm{~mol} / \mathrm{kg}$ while that of the unburnt sites was $18.28 \pm 3.39 \mathrm{~mol} / \mathrm{kg}$. The CEC at a depth of $30-45 \mathrm{~cm} \mathrm{did}$ not have a significant difference between the burnt and the unburnt sites.

Univariate tests of CEC between the three levels of depths showed that there was a significant difference in the CEC between depths. After post hoc tests, the major difference was between $0-15 \mathrm{~cm}$ and $30-45 \mathrm{~cm}$. There was also a significant difference between $0-15 \mathrm{~cm}$ and $15-30 \mathrm{~cm}$, with the mean difference was 2.691 and $\mathrm{P}=0.027$. There was a significant difference in the CEC between the sites burnt at different years. The maximum mean difference was between 2002 and 2014 which was $5.29 \pm 1.46 \mathrm{~mol} / \mathrm{kg}$, and the minimum mean difference was between 2002 and 2012 which was $0.09 \pm 1.46 \mathrm{~mol} / \mathrm{kg}$.

\section{Discussions \\ The effect of fire on plant species diversity Woody vegetation}

The results indicated that fires did not contribute to the major adverse effect on the species diversity of the woody species. The reason may be because most fires experienced at Aberdare Ranges are usually ground fires that do not burn down the woody trees but the barks and sometimes small canopies of the woody trees are burnt. As a consequence, there was no difference in the species diversity of the woody species between the burnt sites and the unburnt sites. Tiny woody plants and seedlings are the only ones usually burnt down by the fires occurring at the Aberdares. The large trees found in Aberdares are resilient to ground fires and are not much affected by the fires. The results agreed with the studies that show that the effects of fire on woody vegetation depend on the intensity and frequency of the fire (Lehmann et al. 2014). Intensity could be low at Aberdares such that they do not have much effect on woody species diversity.
However, there was a significant difference in $\mathrm{DBH}$ between the woody species in the burnt sites and the unburnt sites with the unburnt sites having a higher DBH than that of the burnt sites. All the five burnt sites had a lower mean DBH than their corresponding unburnt sites, meaning that $\mathrm{DBH}$ takes long to increase. $\mathrm{DBH}$ of a tree is crucial in estimating the amount of timber volume in a tree and also in predicting the age of a tree because diameter increment is the only constant non-reversible feature of tree growth (White 1998). This indicates that the fires at Aberdares led to reduce in the timber volume of the trees and also could lead to a wrong prediction of the age of the trees at Aberdares.

The height and canopies of the trees were also smaller in all the burnt sites. There was no burnt site that the height and canopy had recovered. This means that the fires at Aberdares had a negative effect on both height and canopy. The negative impact of fire on $\mathrm{DBH}$, height, and canopy of trees affects the carbon storage ability of tree because carbon is allocated preferentially to the new leaves and roots and then to storage and stem diameter growth (Waring and Pitman 1985). This means that the fires at Aberdares contribute to global warming, by releasing carbon dioxide to the atmosphere during the fires and by reducing carbon storage.

\section{Herbaceous plants}

The data showed that fire causes a decrease in the herbaceous plant species diversity, but one year later, the burnt sites had regenerated and the species diversity of the burnt areas was more diverse than the unburnt areas. The fire burnt almost all herbaceous plants, except Micromera imbricata, Oplisnemus compositus, and Erica arborea. Fire tends to favor species that can tolerate heat stress. Immediately after a fire, the percentage of bare ground is increased which made the land prone to erosion depending on its topography and weather.

In all the other sites except the one that was burnt in 2014 , the species diversity of the herbaceous plants on the burnt sites was higher than on the unburnt sites; an indication that fire triggered the recovery of herbaceous plants. The statistical analysis showed that vegetation cover and height differ significantly between the burnt sites and the unburnt sites. In the sites that had been burnt recently, the height of the vegetation was shorter than the height of the vegetation in their corresponding unburnt sites. In the sites where vegetation had already recovered, the height of the vegetation was even more than the unburnt sites. Fires triggered the regrowth of the herbaceous vegetation, and one year later, the vegetation was taller in the burnt areas other than the site burnt in 2014.

Fires also had the same effect on the number of individuals as the cover and height. The sites that had already recovered had a higher number of individuals compared to the unburnt areas. Only the locations that were recently burnt had fewer numbers of individuals. This was an indication that fire has a positive long-term effect on the herbaceous vegetation. It triggers regeneration of pioneer species whose seeds could be lying dormant in the soil or on the soil surface. 


\section{Effects of fires on animals}

Effects of fires on mammals

The burnt sites that had not yet regenerated possessed fewer animals when compared to the unburnt sites. No animal was found in the site that was burnt in 2014 as the data was collected several days after the fire. They had emigrated out of that area as a consequence of the fire since no vegetation could support the herbivores that support the rest of the food chain. No animals carcass were found at the site meaning that no animal succumbed to the fire.

The site that was burnt in 2013 also had lesser animals compared to the un-burnt site of the same year because the vegetation cover of that burnt site was less than the unburnt site. Furthermore, animals prefer an area with higher vegetation cover where there are more resources.

Individuals were remaining in the burned forest dealt with a different set of problems. Fires brought an immediate negative impact on the wildlife, which in turn can affect the tourism of the country considering that wildlife is one of the major attractions to tourists. Fire leads to the emigration of the wildlife from the burnt areas to the unburnt areas which will lead to the completion of resources in the unburnt areas leading to the exclusion of the weaker wildlife. This ends up in a reduction of the wildlife population.

\section{Effects of fires on birds}

All the burnt sites had fewer birds than the unburnt sites. The number of birds in the other sites burnt in 2013, 2012, 2009 and 2002 had increased although they were still fewer than the unburnt sites. This could be as a result of the reduced canopy of the trees in all the burnt sites considering that vegetation structure and floristic composition influence the availability of food, the risk of predation and availability of nest sites.

Aberdares is an Important Bird Area where many visitors go for bird watching. Fires can lead to negative impacts on bird watching as a result of a decline in bird's diversity which can have disadvantages to the country's economy.

\section{Effects of fire on soil properties}

The fire affected mostly the upper layer at $0-15 \mathrm{~cm}$. Very few effects were observed only at $15-30 \mathrm{~cm}$. This is probably because most fires that occur at Aberdares are less severe and cannot exert effects beyond $15 \mathrm{~cm}$ deep as the effects of fires depend on the fire severity which is determined by the intensity and the duration of the fire.

\section{$p H$}

After two years, there was not much difference in $\mathrm{pH}$ between burnt sites and unburnt sites. This indicated that fire resulted in an increase in $\mathrm{pH}$ and it took almost two years for the $\mathrm{pH}$ to return to its initial levels. The increase in $\mathrm{pH}$ could be a result of ash accretion. Certini (2005) suggests that the response depends on the amount of ash and buffering capacity of the soil. This rise in $\mathrm{pH}$ is because mineral substances are released as oxides or carbonates that usually have an alkaline reaction.

\section{Nitrogen}

The decrease in nitrogen in the recently burnt sites is a result of nitrogen volatilization caused by fire. Nitrogen has low-temperature thresholds and is easily volatilized. Significant losses of nitrogen during the fires could adversely affect long-term site productivity in Aberdare forest ecosystem, particularly if nitrogen replenishment mechanisms are not provided for during post-fire management. Nitrogen is considered the most limiting nutrient in wildland ecosystems, and as such it requires special consideration when managing fire, particularly in nitrogen-deficient ecosystems (Maars et al. 1983)

\section{Organic carbon}

The organic carbon was high in the burnt sires than in the unburnt sites, and this was more evident at $0-15 \mathrm{~cm}$ where there was a significant difference. This is a result of the rapid decomposition of organic matter on the soil during burning to release organic carbon into the underlying soil (Certini 2005). The results were similar to that of a study by Bird et al. (2000), which was carried out on tropical savanna sites in Africa. Low-frequency burning increased soil carbon by about $10 \%$

The effect of organic carbon by fire is determined by the severity of a fire. Fire severity influences the amount of organic matter that is lost. Groeschl and others (1990) revealed that areas burned by a low-severity fire, the forest floor Oi and Oe layers were completely combusted, but the Oa layer remained. High-severity burning also consumed the Oa layer. Of the 10.1 tons/acre $(22.6 \mathrm{Mg} / \mathrm{ha})$ of Carbon present in the forest floor in the unburned areas, no Carbon remained in the high-severity burned areas compared to 9.3 tons/ acre (20.8 Mg/ha) Carbon that was left on the burned areas at low severities.

\section{Potassium}

Increase in potassium in the burnt sites could be due to rapid decomposition of organic matter during burning due to elevated temperatures releasing nutrients to the soil. The organic matter acts as the primary reservoir for several nutrients and, thus, is the source of most potassium (Certini 2005).

\section{Phosphorous}

Phosphorous at $0-15 \mathrm{~cm}$ was significantly lower in the burnt sites than in the unburnt sites. The differences were also observed in the sites that had been burnt less than two years ago but in the sites burnt more than two years ago did not have much difference between the burnt and unburnt sites. Just like nitrogen, phosphorous has low-temperature thresholds and is readily volatilized. This led to a decrease in the amount of phosphorous in the burnt sites.

\section{Cation Exchange Capacity}

As much as fire can make water-soluble cations available for plant uptake, light burns like the ones experienced at Aberdares do not affect the exchange system. 
In conclusion, fires occur every year at Aberdares during the dry season mainly due to arsonists when they want to ferry poles from the forest, charcoal burning, accidents during honey harvesting as the harvesters use fire to drive bees away, and clearing of the forest to create farmlands. Fires brought an immediate negative effect on the herbaceous vegetation but later leads to a positive effect after the vegetation regenerated. The sites that were burnt in 2013, 2012, 2009 and 2002 had more herbaceous vegetation and a higher cover than their unburnt sites. The cover, height and the number of plants increase with time with the site burnt in 2002 having the highest and that burnt in 2014 having the lowest. Animals are also affected by fires. The decrease in vegetation led to a reduction in the wildlife population and diversity. Once vegetation regenerates, wildlife population and diversity tend to increase again. The sites burnt in 2013, 2012, 2009 and 2002 had more wildlife diversity than the unburnt sites since vegetation had regenerated. Loss of vegetation after a fire leads to the emigration of wildlife to the unburnt sites. All the sites burnt had fewer birds than the unburnt sites. This is as a result of the reduced canopy of the trees in the burnt forests. Immediately after a fire, the number of birds utilizing that area reduces drastically as a result of the reduced amount of food and destruction of their nests. Fires also affect the soil properties investigated: nitrogen, potassium, phosphorous, $\mathrm{pH}$, organic carbon, and cation exchange capacity. Fire promotes an increase in $\mathrm{pH}$, potassium, organic carbon and cation exchange capacity due to rapid decomposition of organic matter and leads to a reduction of nitrogen and phosphorous since these two elements are easily volatilized at a low-temperature threshold. Prescribed burning can be adopted by ecosystem managers where controlled fires can be used to burn an ecosystem to increase the herbaceous vegetation, despite the immediate negative effects of fires on species diversity and some soil properties.

\section{REFERENCES}

Ark R. 2011. Environmental, Social and Economic Assessment of the Fencing of the Aberdare Conservation Area. UNEP, Nairobi, Kenya.

Barnes RFW. 1996. Estimating forest elephant abundance by dung counts. In: Kangwana K (ed.). Studying Elephants. Technical Handbook No 7. African Wildlife Foundation, Nairobi.

Black CA. (ed.). 1965a. Method of Soil Analysis, Part 1. Physical and Mineralogical Properties, Including Statistics of Measurement and Sampling. American Society of Agronomy, Inc, Madison, Wisconsin USA

Black CA. (ed.). 1965b. Method of Soil Analysis, Part 2, Chemical and Microbiological Properties. American Society of Agronomy, Inc, Madison, Wisconsin, USA.

Botkin DB. 1990. Discordant Harmonies: A New Ecology for the TwentyFirst Century. Oxford University Press, Oxford.

Butynski T. 1999. Aberdares National Park and Aberdares Forest Reserves Wildlife Fence Placement Study and Recommendations. Africa Biodiversity Conservation Programme. Zoo Atlanta.

Certini G. 2005. Effects of fire on properties of forest soils: a review. Oecologia 143 (1): 1-10. DOI: 10.1007/s00442-004-1788-8
Chuvieco E (ed.). 2009. Earth Observation of Wildland Fires in Mediterranean Ecosystems. Springer-Verlag, Berlin.

Costanza R, d'Arge R, de Groot R, et al. 1997. The value of the world's ecosystem services and natural capital. Nature 387: 253-260. DOI: $10.1038 / 387253 \mathrm{a} 0$

Gonzalez JR, Palahi M, Pukkala T. 2005. Integrating fire risk considerations in forest management planning in Spain-a landscapelevel perspective. Landsc Ecol. 20: 957-970. DOI: 10.1007/s10980005-5388-8

Grier CC. 1975. Wildfire effects on nutrient distribution and leaching in a coniferous ecosystem. Canadian J For Res 5 (4): 599-607. Doi: 10.1139/x75-087

Groeschl DA, Johnson JE, Smith DW. 1990. Forest soil characteristics following wildfire in the Shenandoah National Park, Virginia. In: Nodvin SC, Waldrop TA (ed.). Fire and Environment: Ecological and Cultural Perspectives: Proceedings of an International Symposium. USDA For. Ser. Gen. Tech. Rep. SE-69.

Kevin M. 2007. Quantitative Analysis by the Point-Centered Quarter Method. Department of Mathematics and Computer Science Hobart and William Smith Colleges, New York.

Kozlowski TT. 2002. Physiological ecology of natural regeneration of harvested and disturbed forest stands: implications for forest management. For Ecol Manag 158 (1): 195-221. DOI: 10.1016/S0378-1127(00)00712-X

Lehmann CE, Anderson TM, Sankaran M, et al. 2014. Savanna vegetation-fire-climate relationships differ among continents. Science 343: 548-552.

Lesica P. 1996. Using fire history models to estimate proportions of old growth forest in northwest Montana, USA. Biol Conserv 77: 33-39. DOI: 10.1016/0006-3207(95)00130-1

Long DG, Morgan P, Hardy CC, Swetnam TW, Rollins MG. 2001. Mapping fire regimes across time and space: understanding coarse and fine-scale fire patterns. Intl J Wildland Fire 10 (4): 329-342. DOI: 10.1071/WF01032

Maars RH, Roberts RD, Skeffinton RA, Bradshaw AD. 1983. Nitrogen in the development of ecosystems. In: Lee JA, McNeill S, Rorison IH (eds.). Nitrogen as an Ecological Factor. Blackwell, Oxford, England.

Mehlich A. 1984. Mehlich-3 soil test extractant: a modification of Mehlich-2 extractant. Commun Soil Sci Plant Anal 15 (12): 14091416.

Morgan P, Aplet GH, Haufler JB, Humphries HC, Moore MM, Wilson WD. 1994. Historical range of variability: a useful tool for evaluating ecosystem change. J Sustain For 2 (1-2): 87-111. DOI: 10.1300/J091v02n01_04

Ng'ang'a EM, Kamande LM. 1990: The Vegetation of the Aberdares Mountain Ranges. Department of Resource Surveys and Remote Sensing, Ministry of Planning and National Development. Nairobi, Kenya.

Peech M. 1965. Hydrogen-ion activity. Methods of Soil Analysis. Part 2. Chemical and Microbiological Properties. American Society of Agronomy, Inc, Madison, Wisconsin, USA.

Sturtevant BR, Scheller RM, Miranda BR, Shinneman D, Syphard A. 2009. Simulating dynamic and mixed-severity fire regimes: a processbased fire extension for Landis-II. Ecol Mod 220 (23): 3380-3393. DOI: 10.1016/j.ecolmodel.2009.07.030

Sutherland WJ. 1996. From Individual Behaviour to Population Ecology. Vol. 11. Oxford University Press, Oxford.

Swetnam TW, Allen CD, Betancourt JL. 1999. Applied historical ecology: using the past to manage for the future. Ecol Appl 9: 1189-1206. DOI: 10.1890/1051-0761(1999)009[1189:AHEUTP]2.0.CO;2

Wade DD. 1993. Thinning young loblolly pine stands with fire. Intl J Wildland Fire 3 (3): 169-178. DOI: 10.1071/WF9930169

Waithaka JM. 1994. Monitoring human-elephant conflict through remotely located stations. Pachyderm 27: 66-68.

Waring RH, Pitman GB. 1985. Modifying lodgepole pine stands to change susceptibility to mountain pine beetle attack. Ecology 66: 889-897. DOI: $10.2307 / 1940551$

White J. 1998. Estimating the age of large and veteran trees in Britain. Forestry Commission Information Note 12. Surrey, UK. 